\title{
Indonesian Muslim Intelligentsia and Power
}

\author{
Yudi Latif \\ Singapore: Institute of Southeast Asian \\ Studies, 2008. 544 pages.
}

Yudi Latif's Indonesian Muslim Intelligentsia and Power provides a broad, interdisciplinary, and long-term study of Indonesia's Muslim intelligentsia from the late nineteenth until the early twenty-first century. His methodology stresses the reinterpretation of secondary sources, but does include primary data collected via a documentary and database survey, interviews, a questionnaire, and direct observation. Latif attempts to situate his multigenerational description and analysis within an interdisciplinary framework that includes politics, economics, education, discursive practices, the public sphere, and intellectual traditions. The book consists of seven chapters, including an introduction and a conclusion.

In Chapter 1, "Introduction," the author discusses his main concepts, previous studies, and his interactive approach and methodology. He distinguishes between "intelligentsia" and "intellectuals," noting that "the term 'intelligentsia' referred to a social stratum and indicated the "collective response' of a particular collective identity, as a reflection of common educational criteria, psycho-socio-graphics, value system, habitus and collective memory" (p. 16). Research for both his masters and doctoral degrees contributed to this text.

Chapter 2, "The Formation of the Intelligentsia," focuses on the intelligentsia during the first two decades of the twentieth century while providing the historical context of late-nineteenth-century Dutch colonial rule. Latif 
explains that shifts to Liberal and Ethical Policies issued in a greater concern for native education, as the Ethical Policy extended western education to lesser aristocrats and the upper lower levels of society. The western-educated members of the latter social groups "would become the backbone of the formation of the Indies intelligentsia" (p. 63). Latif describes them as galvanized by "progress" and opines that this "new progressive community" both split from the "old community" of aristocrats and was split internally into secular, adat (customary), and Islamic orientations. He describes how "modernist" and "clerical" intelligentsia expanded the public sphere and formed several proto-nationalist associations.

In Chapter 3, "Making Indonesia, Making Intellectual Political Traditions," Latif describes the second generation of the modern intelligentsia during the 1920s-1940s within the historical context of late colonial rule, the Japanese interregnum, and early political independence. He notes that the intelligentsia, responding to the increasingly repressive "law and order" colonial state of the 1930s, began imagining "Indonesia" in opposition to the "Netherlands East Indies." Japanese mobilization of militarized organizations facilitated greater links between the politicized intelligentsia and the uneducated masses, which led to the growth of popular solidarity and nationalism. Latif writes that although the archipelago's seven political traditions (viz., Islamic reformist-modernism, Islamic traditionalism, communism, socialism, secular nationalism, and Christian and military secularism) represent significant fragmentation in the Muslim as well as the secular camps, it is exactly these two camps that were often forced to unite within competitive power struggles. Moreover, the marginalization of political Islam under Dutch and Japanese rule left the Muslim camp behind in modern educational and political schooling and at a loss in pre- and post-independence power struggles. Thus, he argues the Muslim camp developed a "minority complex" and spent the rest of the twentieth century trying to Islamize the intelligentsia.

Chapter 4, "Intelligentsia as the Political Elite of the New Nation," discusses the turbulent period from 1945-65, which saw a brief armed struggle for independence, a failed attempt at parliamentary democracy, and the collapse of the first postcolonial state under the secular nationalists' leadership. Latif argues that contrary to Marxist expectations, it was the secular and clerical intelligentsia hailing from various class backgrounds, rather than the dominant economic class, that became independent Indonesia's dominant political elite. The secular nationalist camp's leadership, defeating the Muslim proposal of establishing a formal state-Shari ah relationship, set out to implement parliamentary democracy. He posits that this "democratic 
experiment" eventually failed because the lower class and less educated people were not included, the tiny political elite was deeply divided, and collective social learning was absent. He describes how contesting political traditions became power struggles and led to the rise of the secular military intelligentsia. This modern-educated military camp and the Indonesian Communist Party supported President Sukarno as he replaced the embattled parliamentary system with the more authoritarian project of "guided democracy." Rather than emphasizing the shady military maneuvers involved in this transfer of power to the Suharto (New Order) regime, he elaborates upon the unprecedented growth of Muslim student organizations, asserting that they "played a very decisive role in the student demonstrations of the mid-1960s leading up to the fall of [the] Sukarno regime" (p. 307).

In Chapter 5, "The New Order's Repressive-Developmentalism and the Islamic Intellectual Response," Latif concentrates on the period roughly from 1966 to the late 1980s, noting that the military intelligentsia, partnering with socialist and Christian intellectuals, dominated the New Order regime. He observes that the hegemonic military intelligentsia stressed aggressive economic development and modernization and repressed all perceived threats to this project. Islamic political parties were disbanded and reorganized, and Muslim organizations were pressured to adopt the state ideology as their basis. Latif opines that the second-generation intelligentsia largely opted for non-cooperation by furthering their Islamizing goals via education and dakwah, while the third-generation intelligentsia largely cooperated with the state. The fourth generation was divided into what he labels the proponents of dakwah and "renewal." Although many members of the Muslim intelligentsia considered themselves part of the "renewal" movement, including those in the Nahdlatul Ulama and Muhammadiyah, Latif designates only those who espoused "the agenda of liberalizing Islamic thinking" as "the renewal movement" (p. 358). Rather than explicating the intelligentsia's cultural codes, he propounds this problem by labeling dakwah activists as "reactionary Islamists" or "moderate-reactionary Islamists." Nevertheless, he believes that the dakwah and "renewal" movements found common ground in Islamic spiritualism, art, and economics.

Chapter 6, "The Rise and Decline of the Association of Indonesian Muslim Intelligentsia (ICMI)," discusses the New Order regime's last decade and the beginning of the reform era. Although ICMI's rise was significant in marking the Muslim intelligentsia's improved educational position, the study would have been better served by a broader examination of the various sectors during this time period, quite notably the military intelligentsia 
who remained dominant. Latif concludes by summarizing his findings of synchronic and diachronic change and continuity within and across six generations of Indonesia's Muslim intelligentsia. His broad, interdisciplinary, and interactive approach makes this text very appealing to historians, sociologists, anthropologists, and those involved in cultural, religious, and Southeast Asian studies. 